\title{
"Explaining the efficiency of anaesthesiology and intensive care wards in the Slovak Republic"
}

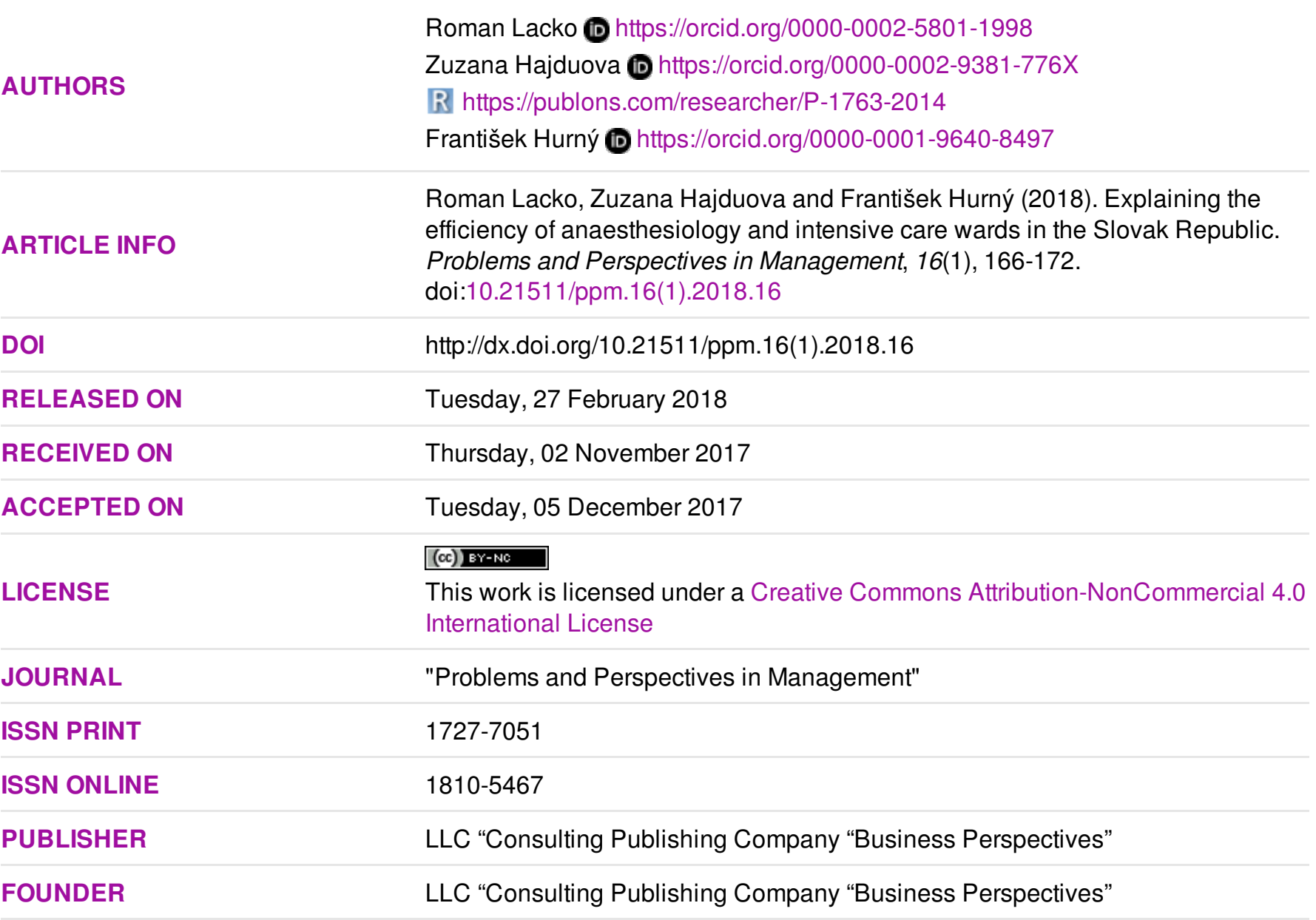

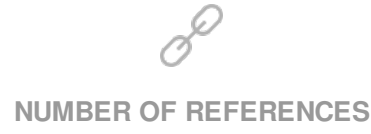

26

\section{NUMBER OF FIGURES}

2
$-=-$
$-=-$

NUMBER OF TABLES

5

(C) The author(s) 2022. This publication is an open access article. 


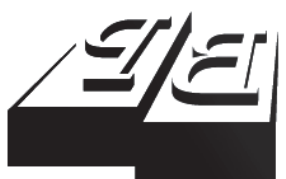

BUSINESS PERSPECTIVES

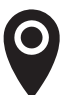

LLC “CPC "Business Perspectives" Hryhorii Skovoroda lane, 10, Sumy, 40022, Ukraine

www.businessperspectives.org

Received on: $2^{\text {nd }}$ of November, 2017 Accepted on: $5^{\text {th }}$ of December, 2017

(C) Roman Lacko, Zuzana Hajduová, František Hurný, 2018

Roman Lacko, Ph.D., Faculty of Business Economics with seat in Košice, University of Economics in Bratislava, Slovak Republic.

Zuzana Hajduová, Ph.D., Associate Professor, Faculty of Business Economics with seat in Košice, University of Economics in Bratislava, Slovak Republic.

František Hurný, Ing., Doctoral Student, Faculty of Business Economics with seat in Košice, University of Economics in Bratislava, Slovak Republic.

\section{(ㄷ)(1) $(9$}

This is an Open Access article, distributed under the terms of the Creative Commons Attribution-NonCommercial 4.0 International license, which permits re-use, distribution, and reproduction, provided the materials aren't used for commercial purposes and the original work is properly cited.
Roman Lacko (Slovak Republic), Zuzana Hajduová (Slovak Republic),

František Hurný (Slovak Republic)

\section{EXPLAINING THE EFFICIENCY OF ANAESTHESIOLOGY AND INTENSIVE CARE WARDS IN THE SLOVAK REPUBLIC}

\begin{abstract}
In this article, the authors measure and evaluate the efficiency of anesthesiology and intensive care wards in the Slovak Republic using the suitable methods and check suitability of methods and variables used in the Slovak healthcare environment. Nowadays, trends are towards modification of basic data envelopment analysis (DEA) incorporating other quantitative methods. In this study, the authors examined the influence of contextual variables on CCR DEA efficiency scores. Variables Ageing index and Unemployment rate had unexpected sign/effect on efficiency. Variables Average length of stay and Bed occupancy rate seem to be adequate to be used and checked for significance in terms of selected wards of the Slovak Republic healthcare. Such types of articles are completely missing in the Slovak Republic. Methods and variables the authors have used could be modificated to needs of individual wards. These findings could be used to build information system of efficiency in the Slovak healthcare within cooperation with National Health Information Center.
\end{abstract}

\section{Keywords \\ two-step, data envelopment analysis, truncated regression, Slovak Republic, healthcare}

\section{JEL Classification I18, C24, C67}

\section{INTRODUCTION}

Data envelopment analysis (DEA) is a well-known method which is used to evaluate the efficiency of decision making units. This method is based on the use of linear programming. It was founded in the 70s and originally was used to measure the efficiency of non-profit organizations (hospitals, schools, public administration, etc.). Thereafter the field of its use spread to the area of enterprises, national economies, different sectors or sport. Nowadays we know many models of this analysis, which finds application in measurement of efficiency. We can also mention the CCR, BCC or two-stage DEA as best known and the most used models of DEA. In this study, we focus on evaluation of efficiency in selected wards of Slovak hospitals using two-step DEA approach.

\section{LITERATURE REVIEW}

Based on our study of literature, we have found that the most commonly used regressions in health sector used in the second step of two-step DEA are truncated regression and Tobit regression.

Araújo et al. (2013), using truncated regression, analyzed profit hospitals in Brazil. They used number of beds as an input and inpatients as an output. Kounetas and Papathanassopoulos (2013) used similar 
input (beds) and output (inpatient days). They evaluated one hundred and fourteen hospitals in Greece. Mitropoulos et al. (2012) also dealt with the evaluation of hospitals in Greece using truncated regression. They analyzed ninety-six public hospitals. Salaries were used as an input, introduction pathologic as an output. Same regression and sample of hospitals in Tunisia were used in the study of Chaabouni and Abednnadher (2012). Also, Blank and Valdmanis (2010) and Blank and Hulst (2010) used this type of regression in their studies focused on health sector in the Netherlands. Twostep DEA using truncated regression in combination with SFA were used in the study of Varabyova and Shreyogg (2013). Number of beds as an input and number of discharges as an output were used in their work.

Regarding Tobit regression, Matranga et al. (2014) analyzed four hundred eighty-one hospitals by ownership in Italy. They used medical staff as an input and number of discharges as an output. Also, Jehu-Appiah et al. (2014) evaluated efficiency of Ghanaian hospitals using the sample of hospitals by ownership with number of beds as an input and number of inpatients as an output. Twenty-six non-profit hospitals were analyzed in the study of Kalogeropoulou et al. (2012) using Tobit regression. There exist studies dealing with the evaluation of the efficiency in some Asian countries. Rahman and Capitman (2012) analyzed one hundred eighty-five profit hospitals in Bangladesh, $\mathrm{Hu}$ et al. (2012) dealt with hospitals in China, and Foo et al. (2015) analyzed ophthalmology wards in Malaysia.

The combination of both the abovementioned regressions were used in study of Gholami et al. (2015). They used salaries as an input and net patient revenues as on output in one hundred and eighty-seven hospitals in the USA. We can find another combination of regressions in Kaya Samut and Cafri (2015) study - they used Malmquist Index regression with Tobit regression.

In addition to these two regressions, there exist also other types methods used in second step of two-step DEA. First, ordinary least squares (OLS) regression was used in the studies of Castelli et al. (2015), Hadad et al. (2011) and Valdmanis et al. (2008). We can also find multiple regression as a part of second step. Harrison et al. (2010) used this regression when evaluating university hospitals in the USA. Same regression with Malmquist regression served for evaluation of public hospitals in Turkey (Gok \& Sezen, 2013). Number of beds as an input and number of days of bed occupancy as an output were used. Seemingly unrelated regressions (SUR) and partial least squares (PLS) regression belong to the less widely used regressions. Karagiannis (2013) used SUR for evaluation of public hospitals in Greece. PLS regressions were used in the study of Djema and Djerdjouri (2012) who analyzed one hundred and seventy-four hospitals in Algeria.

\section{METHODOLOGY}

In the first step of two-step DEA, we have to calculate the efficiency scores using CCR output-oriented DEA model according to Cooper et al's. (2007) input-oriented model of linear programming often called as "Farell efficiency" as a reciprocal value $1 / \theta$.

In the second step, we need to use regression to check the influence of explanatory variables on efficiency. For this purpose, truncated regression and Tobit regression are often used. To get consistent estimates of regression model, we need to use the method/algorithm proposed by Simar and Wilson (2007) which by using the double bootstrap mechanism provides bias corrected DEA efficiencies suitable for using in regression models. We will use truncated regression model which has the following form:

$$
\delta_{i}=z_{i} \beta+\varepsilon_{i}
$$

$i=1, \ldots, n$,

where $\delta_{i}$ is DEA efficiency score of selected DMU, $z_{i}$ is set of explanatory variables, $\beta$ are regression coefficients and $\varepsilon_{i}$ is standard error. If we use the algorithm proposed by Simar and Wilson (2007) truncated regression model will have the following form:

$$
\widehat{\delta}_{i}^{B C} \approx z_{i} \beta+\varepsilon_{i},
$$

$i=1, \ldots, n, \varepsilon_{i} \geq 1-z_{i} \beta, \varepsilon_{i} \sim N\left(0, \sigma_{\varepsilon}^{2}\right)$, 
Table 1. Descriptive statistics of input variables

Source: Own processing according to data provided by NHIC.

\begin{tabular}{|c|c|c|c|c|c|}
\hline Statistic & Number of beds & Number of doctors & Number of nurses & Material costs & Operational costs \\
\hline $\mathrm{N}$ & 48 & 48 & 48 & 48 & 48 \\
\hline Mean & 59.104 & 78.551 & 199.521 & 2776132.000 & 411253.600 \\
\hline St. Dev. & 24.227 & 32.236 & 76.572 & 2045627.000 & 305053.500 \\
\hline Min & 32.000 & 44.440 & 107.370 & 860763.000 & 152375.000 \\
\hline $\operatorname{Max}$ & 109.000 & 158.590 & 371.670 & 8316696.000 & 1217190.000 \\
\hline
\end{tabular}

where $\widehat{\delta}_{i}^{B C}$ is bias corrected efficiency using the second algorithm proposed by Simar and Wilson (2007).

Data will be truncated left to point 1 , because output efficiencies are in interval 1 to infinity. The main point of this regression is that explanatory and dependent variables under this boundary are latent. Tobit regression assumes that only explanatory variable is latent one.

General form of Tobit regression is expressed as follows:

$$
\delta_{i}^{*}=z_{i} \beta+\varepsilon_{i},
$$

$i=1, \ldots, n$.

\section{DATA}

We chose as the object of research anaesthesiology and intensive care wards of secondary health care providers. According to the data provided by the National Health Information Center (NHIC), we chose to evaluate the efficiency between 8 regions in Slovakia according to NUTS 3 classification. Data were provided for 6 years (from 2009 till 2014). We selected DEA window analysis, which means that ward in the selected year will be taken as unique DMU.

As input variables for DEA CCR model we chose, according to the most used variables presented in Hadji et al. (2014) and according to the section

Table 2. Descriptive statistics of output variables
Introduction and availability of variables provided by NHIC, the following variables: Number of beds, Number of doctors, Number of nurses, Material costs and Operational costs. Variables Number of doctors and Number of nurses were considered as fixed. As output variables, we chose Number of inpatients, Number of inpatient days and Total revenues. As explanatory variables, we selected following variables: Average length of stay, Bed occupancy rate divided by 100 , Citizens in age 15 to 64 divided by 100, Ageing index divided by 100 (rate of citizens in age $0-14$ to citizens in age 65 and more), Mortality of new-borns to 1000 inhabitants divided by 10 and Unemployment rate divided by 10 . These data were provided by NCHI and Eurostat. Then we constructed panel with 48 DMUs.

\section{RESULTS}

Table 1 shows selected descriptive statistics of input variables, which were used for DEA efficiencies computation.

The average number of beds was at value of almost 60 beds. The minimum level of the number of beds was recorded in the Zilina region, on the contrary, the highest in Bratislava. The lowest number of doctors and nurses was reported in the Trnava region. The highest operating costs were recorded in Bratislava and Kosice. It is similar in the case of material costs. The next Table 2 shows the output characteristics of DEA models.

Source: Own processing according to data provided by NHIC.

\begin{tabular}{|c|c|c|c|}
\hline Statistic & Number of inpatients & Number of inpatient days & Total revenues \\
\hline $\mathrm{N}$ & 48 & 48 & 48 \\
\hline Mean & 2287.958 & 12092.270 & 7720145.000 \\
\hline St. Dev. & 1316.909 & 5007.014 & 5461431.000 \\
\hline Min & 841.000 & 5987.000 & 2450419.000 \\
\hline $\operatorname{Max}$ & 5031.000 & 20807.000 & 19344061.000 \\
\hline
\end{tabular}


Table 3. Descriptive statistics of explanatory variables

Source: Own processing according to data provided by NHIC and Eurostat.

\begin{tabular}{|c|c|c|c|c|c|c|}
\hline Statistic & ALOS & Bed occupancy & 15-64 & Ageing index & $\begin{array}{l}\text { Mortality of } \\
\text { New-borns }\end{array}$ & $\begin{array}{c}\text { Unemployment } \\
\text { rate }\end{array}$ \\
\hline $\mathrm{N}$ & 48 & 48 & 48 & 48 & 48 & 48 \\
\hline Mean & 5.767 & 0.57948 & 0.7189 & 0.86577 & 0.3049 & 1.3017 \\
\hline St. Dev. & 0.942 & 0.04181 & 0.0098 & 0.16597 & 0.1314 & 0.4845 \\
\hline Min & 3.900 & 0.48700 & 0.7018 & 0.56520 & 0.0900 & 0.4360 \\
\hline Max & 7.300 & 0.67900 & 0.7376 & 1.11410 & 0.6300 & 2.0810 \\
\hline
\end{tabular}

The average number of hospitalizations in the different regions for the period was nearly 2,300 patients. Most patients were hospitalized in the Kosice region, least in Trnava. Top revenues were reached in Bratislava and Kosice, on the contrary, Trnava and Trencin were the regions with lowest values of this variable. Table 3 shows the descriptive statistics of explanatory variables.

The average of ALOS (Average length of stay) was approximately 5.8 days. The highest values were recorded in the Trencin and Trnava region and the lowest in the Kosice region. Bed occupancy level fluctuated at around $60 \%$. The following table shows the test results of DEA CCR model and BCC for wards of anaesthesiology and intensive care. Table 4 shows the computed efficiency scores of individual wards.

In the case of wards of A\&IC, it can be argued that according to results of model CCR, only Banska Bystrica region is efficient. In the model BCC, Banska Bystrica region was joined by the region of Trnava, which was by CCR, on the con-

Table 4. Efficiency scores and slacks

Source: Own processing

\begin{tabular}{|c|c|c|c|c|c|c|c|c|}
\hline DMU & CCR out ef. & N. of beds & $\begin{array}{c}\text { Material } \\
\text { costs }\end{array}$ & $\begin{array}{c}\text { Operational } \\
\text { costs }\end{array}$ & BCC out ef. & N. of beds & $\begin{array}{c}\text { Material } \\
\text { costs }\end{array}$ & $\begin{array}{c}\text { Operational } \\
\text { costs }\end{array}$ \\
\hline BA14 & 1.00 & 0.00 & 0.00 & 0.00 & 1.00 & 0.00 & 0.00 & 0.00 \\
\hline BA13 & 1.03 & 0.00 & 0.00 & 162485.93 & 1.02 & 0.00 & 5146.79 & 164533.72 \\
\hline BA12 & 1.03 & 0.00 & 0.00 & 136921.93 & 1.03 & 0.00 & 182049.14 & 0.00 \\
\hline BA11 & 1.02 & 0.00 & 595531.37 & 113555.41 & 1.02 & 0.00 & 573419.64 & 116718.92 \\
\hline BA10 & 1.00 & 0.00 & 0.00 & 0.00 & 1.00 & 0.00 & 0.00 & 0.00 \\
\hline BA09 & 1.00 & 0.00 & 0.00 & 0.00 & 1.00 & 0.00 & 0.00 & 0.00 \\
\hline TT14 & 1.17 & 0.00 & 51978.63 & 0.00 & 1.00 & 0.00 & 0.00 & 0.00 \\
\hline TT13 & 1.18 & 0.00 & 49521.67 & 0.00 & 1.00 & 0.00 & 0.00 & 0.00 \\
\hline TT12 & 1.24 & 0.00 & 92678.76 & 0.00 & 1.00 & 0.00 & 0.00 & 0.00 \\
\hline TT11 & 1.18 & 0.00 & 37623.51 & 0.00 & 1.00 & 0.00 & 0.00 & 0.00 \\
\hline TT10 & 1.19 & 0.00 & 30539.87 & 0.00 & 1.00 & 0.00 & 0.00 & 0.00 \\
\hline TT09 & 1.22 & 0.00 & 77537.31 & 0.00 & 1.00 & 0.00 & 0.00 & 0.00 \\
\hline TN14 & 1.12 & 0.00 & 0.00 & 0.00 & 1.03 & 1.46 & 0.00 & 0.00 \\
\hline TN13 & 1.03 & 0.00 & 0.00 & 0.00 & 1.00 & 0.00 & 0.00 & 0.00 \\
\hline TN12 & 1.00 & 0.00 & 0.00 & 0.00 & 1.00 & 0.00 & 0.00 & 0.00 \\
\hline TN11 & 1.09 & 1.17 & 0.00 & 0.00 & 1.00 & 0.00 & 0.00 & 0.00 \\
\hline TN10 & 1.01 & 4.62 & 0.00 & 0.00 & 1.00 & 0.00 & 0.00 & 0.00 \\
\hline TN09 & 1.00 & 0.00 & 0.00 & 0.00 & 1.00 & 0.00 & 0.00 & 0.00 \\
\hline NR14 & 1.07 & 3.46 & 0.00 & 0.00 & 1.06 & 2.19 & 0.00 & 0.00 \\
\hline NR13 & 1.06 & 4.86 & 56754.76 & 0.00 & 1.06 & 2.15 & 45997.25 & 0.00 \\
\hline NR12 & 1.00 & 0.00 & 0.00 & 0.00 & 1.00 & 0.00 & 0.00 & 0.00 \\
\hline NR11 & 1.00 & 0.00 & 0.00 & 0.00 & 1.00 & 0.00 & 0.00 & 0.00 \\
\hline NR10 & 1.07 & 5.80 & 32605.41 & 0.00 & 1.03 & 2.83 & 476047.35 & 0.00 \\
\hline NR09 & 1.08 & 1.30 & 0.00 & 0.00 & 1.06 & 0.00 & 73643.06 & 0.00 \\
\hline ZA14 & 1.00 & 0.00 & 0.00 & 0.00 & 1.00 & 0.00 & 0.00 & 0.00 \\
\hline ZA13 & 1.01 & 0.00 & 0.00 & 41723.98 & 1.00 & 0.00 & 0.00 & 27761.88 \\
\hline ZA12 & 1.07 & 0.00 & 0.00 & 117180.73 & 1.00 & 0.00 & 0.00 & 0.00 \\
\hline ZA11 & 1.09 & 0.00 & 0.00 & 46668.29 & 1.00 & 0.00 & 0.00 & 0.00 \\
\hline ZA10 & 1.12 & 0.00 & 0.00 & 11214.89 & 1.01 & 0.00 & 0.00 & 35219.45 \\
\hline ZA09 & 1.17 & 0.00 & 0.00 & 70629.57 & 1.06 & 0.00 & 0.00 & 60073.34 \\
\hline
\end{tabular}


Table 4 (cont.). Efficiency scores and slacks

\begin{tabular}{|c|c|c|c|c|c|c|c|c|}
\hline DMU & CCR out ef. & N. of beds & $\begin{array}{c}\text { Material } \\
\text { costs }\end{array}$ & $\begin{array}{c}\text { Operational } \\
\text { costs }\end{array}$ & BCC out ef. & N. of beds & $\begin{array}{c}\text { Material } \\
\text { costs }\end{array}$ & $\begin{array}{c}\text { Operational } \\
\text { costs }\end{array}$ \\
\hline BB14 & 1.00 & 0.00 & 0.00 & 0.00 & 1.00 & 0.00 & 0.00 & 0.00 \\
\hline BB13 & 1.00 & 0.00 & 0.00 & 0.00 & 1.00 & 0.00 & 0.00 & 0.00 \\
\hline BB12 & 1.00 & 0.00 & 0.00 & 0.00 & 1.00 & 0.00 & 0.00 & 0.00 \\
\hline BB11 & 1.00 & 0.00 & 0.00 & 0.00 & 1.00 & 0.00 & 0.00 & 0.00 \\
\hline BB10 & 1.00 & 0.00 & 0.00 & 0.00 & 1.00 & 0.00 & 0.00 & 0.00 \\
\hline BВ09 & 1.00 & 0.00 & 0.00 & 0.00 & 1.00 & 0.00 & 0.00 & 0.00 \\
\hline PO14 & 1.00 & 0.00 & 0.00 & 0.00 & 1.00 & 0.00 & 0.00 & 0.00 \\
\hline PO13 & 1.00 & 0.00 & 0.00 & 0.00 & 1.00 & 0.00 & 0.00 & 0.00 \\
\hline PO12 & 1.00 & 0.00 & 0.00 & 0.00 & 1.00 & 0.00 & 0.00 & 0.00 \\
\hline PO11 & 1.00 & 0.00 & 0.00 & 0.00 & 1.00 & 0.00 & 0.00 & 0.00 \\
\hline PO10 & 1.00 & 0.00 & 0.00 & 0.00 & 1.00 & 0.00 & 0.00 & 0.00 \\
\hline PO09 & 1.01 & 1.45 & 0.00 & 4496.95 & 1.01 & 1.22 & 0.00 & 1796.63 \\
\hline KE14 & 1.01 & 0.00 & 0.00 & 323714.43 & 1.00 & 0.00 & 0.00 & 0.00 \\
\hline KE13 & 1.00 & 0.00 & 0.00 & 0.00 & 1.00 & 0.00 & 0.00 & 0.00 \\
\hline KE12 & 1.00 & 0.00 & 0.00 & 0.00 & 1.00 & 0.00 & 0.00 & 0.00 \\
\hline KE11 & 1.03 & 0.00 & 0.00 & 73855.66 & 1.02 & 0.57 & 0.00 & 36526.81 \\
\hline KE10 & 1.00 & 0.00 & 0.00 & 0.00 & 1.00 & 0.00 & 0.00 & 0.00 \\
\hline KE09 & 1.00 & 0.00 & 0.00 & 0.00 & 1.00 & 0.00 & 0.00 & 0.00 \\
\hline
\end{tabular}

Note: BA - Bratislava region, TT - Trnava region, TN - Trencin region, NR - Nitra region, ZA - Zilina region, BB - Banska Bystrica region, $\mathrm{PO}$ - Presov region, $\mathrm{KE}$ - Kosice region, number after abbreviation is the year in which DMUs were evaluated.

trary, the most inefficient region. Distinct need for a reduction in material costs occurred by CCR only in Trnava and Bratislava. Operating costs were higher in Bratislava, Kosice and Zilina regions. Table 5 shows the results of regressions for A\&IC wards. We should note, that output efficiency scores were used. It means that lower value of efficiency is better score of efficiency, since the values are ranging from 1 (which means efficient DMU) to infinity.

One could argue that the variables Average length of stay, Bed occupancy rate, Ageing index and Unemployment rate were statistically significant for both models. Unexpected element was the influence of the variables Ageing index and Unemployment rate, which had a negative/unexpected effect. It means that by improving these variables to better levels, efficiency rate is worsening. Variable Mortality of new-borns for these models is not appropriate at all, so is the variable of the population aged 15-64 years. It should be noted the fact that the dependent variable of regression models was CCR efficiency, since the efficiency of BCC for those wards is not appropriate, models were insignificant.

Table 5. Regression models results

Source: Own processing.

\begin{tabular}{|c|c|c|}
\hline \multirow{3}{*}{ Explanation variables } & \multicolumn{2}{|c|}{ Dependent variable: } \\
\hline & \multicolumn{2}{|c|}{ CCR output efficiency } \\
\hline & Tobit & Truncated regression \\
\hline \multirow{2}{*}{ ALOS } & $0.041^{* * *}$ & $0.069^{* * *}$ \\
\hline & $(0.007)$ & $(0.014)$ \\
\hline \multirow{2}{*}{ Bed occupancy } & $-0.877^{* * *}$ & $-1.485^{* * *}$ \\
\hline & $(0.176)$ & $(0.359)$ \\
\hline \multirow{2}{*}{$15-64$} & -0.844 & -3.316 \\
\hline & $(1.143)$ & $(2.045)$ \\
\hline \multirow{2}{*}{ Ageing index } & $-0.152^{* * *}$ & $-0.258^{* * *}$ \\
\hline & $(0.054)$ & $(0.087)$ \\
\hline \multirow{2}{*}{ Mortality of new-borns } & -0.015 & -0.107 \\
\hline & $(0.066)$ & $(0.128)$ \\
\hline \multirow{2}{*}{ Unemployment rate } & $-0.062^{* * *}$ & $-0.152^{* * *}$ \\
\hline & $(0.016)$ & $(0.042)$ \\
\hline
\end{tabular}


Table 5 (cont.). Regression models results

\begin{tabular}{|c|c|c|}
\hline \multirow{3}{*}{ Explanation variables } & \multicolumn{2}{|c|}{ Dependent variable: } \\
\hline & \multicolumn{2}{|c|}{ CCR output efficiency } \\
\hline & Tobit & Truncated regression \\
\hline \multirow{2}{*}{ Intercept } & $2.159 * *$ & $4.320^{* * *}$ \\
\hline & $(0.900)$ & $(1.661)$ \\
\hline \multirow{2}{*}{$\log$ (scale) } & $-3.317^{* * *}$ & - \\
\hline & 0.102 & - \\
\hline \multirow{2}{*}{ Sigma } & - & $0.043^{* * *}$ \\
\hline & - & $(0.006)$ \\
\hline Observations & 48 & 48 \\
\hline Log likelihood & 91.092 & 115.04 \\
\hline Wald test $(\mathrm{df}=8)$ & $117.841^{* * *}$ & - \\
\hline R-squared & 0.7106 & 0.6855 \\
\hline
\end{tabular}

Note: ${ }^{\star} p<0.1 .{ }^{* *} p<0.05 .{ }^{* * *} p<0.01$.

\section{CONCLUSION}

The aim of this work is to use a slight modification of modern approach for assessment of the impact of explanatory variables with respect to efficiency. Integration of scientific research areas with medical practice is necessary for the potential application of the recommendations of the various models, because one side of the issue is recommendations of models and the second is incorporating the changes in the hospitals and organizational processes. In accordance with the objectives and tasks of the European Union in the field of healthcare, the Slovak Republic should establish a way to substantial changes in health care and as a framework for these changes, there should be utilized strategies and objectives of common European area, which include an emphasis on the integration of science and research not only into health management, but also at specific hospitals. Such types of articles are completely missing in the Slovak Republic. Methods and variables we have used could be changed to needs of individual wards. These findings could be used to build information system of efficiency in Slovak healthcare within cooperation with National Healthcare Information Center. Options for further research are obvious. Results also showed that differences between regions should be considered. So, we strongly recommend to research if there are possibilities to include these differences into health policies.

\section{REFERENCES}

1. Araújo, C., Barros, C. P., \& Wanke, P. (2013). Efficiency determinants and capacity issues in Brazilian for-profit hospitals. Health Care Management Science, 17(2), 126-138. https://doi.org/10.1007/ s10729-013-9249-8

2. Blank, J. L. T., \& Valdmanis, V. G. (2010). Environmental factors and productivity on Dutch hospitals: A semi-parametric approach. Health Care Management Science, 13(1), 27-34. https://doi.org/10.1007/ s10729-009-9104-0

3. Blank, J. L. T., \& Van Hulst, B. L. (2010). Governance and performance: The performance of Dutch hospitals explained by governance characteristics. Journal of Medical Systems, 35(5), 991-999. https://doi.org/10.1007/ s10916-010-9437-8

4. Castelli, A., Street, A., Verzulli, R., \& Ward, P. (2015). Examining variations in hospital productivity in the English NHS. European Journal of Health Economics, 16(3), 243-254. https://doi.org/10.1007/ s10198-014-0569-5

5. Cooper, W. W., Seiford, L. M., \& Tone, K. (2007). Data Envelopment Analysis. A comprehensive
Text with Models, Applications, References and DEA-Solver software. New York: Springer.

6. Djema, H., \& Djerdjouri, M. (2012). A two-stage DEA with partial least squares regression model for performance analysis in healthcare in Algeria. International Journal of Applied Decision Sciences, 5(2), 118141. https://doi.org/10.1504/ IJADS.2012.046506

7. Foo, C. Y., Lim, K. K., Sivasampu, S., Dahian, K. B., \& Goh, P. P. (2015). Improving the effectiveness of service delivery in 
the public healthcare sector: the case of ophthalmology services in Malaysia. BMC Health Services Research, 15(1). https://doi. org/10.1186/s12913-015-1011-0

8. Gholami, R., Añón Higón, D., \& Emrouznejad, A. (2015). Hospital performance: Efficiency or quality? Can we have both with IT? Expert Systems with Applications, 42(12), 53905400. https://doi.org/10.1016/j. eswa.2014.12.019

9. Gok, M. S., \& Sezen, B. (2013). Analyzing the ambiguous relationship between efficiency, quality and patient satisfaction in healthcare services: The case of public hospitals in Turkey. Health Policy, 111(3), 290-300. https://doi.org/10.1016/j.healthpol.2013.05.010

10. Hadad, S., Hadad, Y., \& SimonTuval, T. (2011). Determinants of healthcare system's efficiency in OECD countries. European Journal of Health Economics, 14(2), 253-265. https://doi.org/10.1007/ s10198-011-0366-3

11. Hadji, B., Meyer, R., Melikeche, S., Escalon, S., \& Degoulet, P. (2014). Assessing the Relationships Between Hospital Resources and Activities: A Systematic Review. Journal of Medical Systems, 38(10). https://doi.org/10.1007/s10916014-0127-9

12. Harrison, J. P., Lambiase, L. R., \& Zhao, M. (2010). Organizational factors associated with quality of care in US teaching hospitals. Journal of Health Care Finance, 36(3), 1-12.

13. Hu, H.-H., Qi, Q., \& Yang, C.H. (2012). Analysis of hospital technical efficiency in China: Effect of health insurance reform. China Economic Review, 23(4), 865-877. https://doi.org/10.1016/j. chieco.2012.04.008

14. Chaabouni, S., \& Abednnadher, C. (2012). Efficiency of public hospitals in Tunisia: a DEA with bootstrap application. International Journal of Behavioural and Healthcare Research, 3(3-4), 198-211. https://doi.org/10.1504/IJBHR.2012.051380
15. Jehu-Appiah, C., Sekidde, S., Adjuik, M., Akazili, J. C., Almeida, S. D., Nyonator, F., Baltussen, R., Asbu, E. Z., \& Kirigia, J. M. (2014). Ownership and technical efficiency of hospitals: Evidence from Ghana using data envelopment analysis. Cost Effectiveness and Resource Allocation, 12(1). https://doi. org/10.1186/1478-7547-12-9

16. Kalogeropoulou, M., Ioannidis, A., \& Mourdoukoutas, P. (2012). Measuring performance in non-profit organisations: the case of Greek public hospitals. International Journal of Behavioural and Healthcare Research, 3(3-4), 212-225. https://doi.org/10.1504/IJBHR.2012.051381

17. Karagiannis, R. (2013). A systemof-equations two-stage DEA approach for explaining capacity utilization and technical efficiency. Annals of Operations Research, 227(1), 25-43. https://doi. org/10.1007/s10479-013-1367-7

18. Katharakis, G., Katharaki, M., \& Katostaras, T. (2014). An empirical study of comparing DEA and SFA methods to measure hospital units' efficiency. International Journal of Operational Research, 21(3), 341-364. https://doi.org/10.1504/ IJOR.2014.065413

19. Kaya Samut, P., \& Cafri, R. (2015). Analysis of the Efficiency Determinants of Health Systems in OECD Countries by DEA and Panel Tobit. Social Indicators Research, 129(1), 113-132. https:// doi.org/10.1007/s11205-0151094-3

20. Kounetas, K., \& Papathanassopoulos, F. (2013). How efficient are Greek hospitals? A case study using a double bootstrap DEA approach. European Journal of Health Economics, 14(6), 979-994. https:// doi.org/10.1007/s10198-0120446-Z

21. Matranga, D., Bono, F., Casuccio, A., Firenze, A., Marsala, L., Giaimo, R., Sapienza, F., \& Vitale, F. (2014). Evaluating the effect of organization and context on technical efficiency:
A second-stage dea analysis of Italian hospitals. Epidemiology Biostatistics and Public Health, 11(1), 1-11.

22. Mitropoulos, P., Mitropoulos, I., \& Sissouras, A. (2012). Managing for efficiency in health care: The case of Greek public hospitals. European Journal of Health Economics, 14(6), 929-938. https:// doi.org/10.1007/s10198-0120437-0

23. Rahman, M. A., \& Capitman, J. A (2012). Factors Affecting Profit Efficiency of Private Hospitals in Bangladesh: Are Urban Hospitals More Profit-Efficient? Journal of Health Management, 14(2), 83-96. https://doi. org/10.1177/097206341201400201

24. Simar, L., \& Wilson, P. W. (2007). Estimation and inference in twostage, semi-parametric models of production processes. Journal of econometrics, 136(1), 31-64. https://doi.org/10.1016/j.jeconom.2005.07.009

25. Valdmanis, V. G., Rosko, M. D., \& Mutter, R. L. (2008). Hospital quality, efficiency, and input slack differentials. Health Services Research, 43(5P2), 1830-1848. https://doi.org/10.1111/j.14756773.2008.00893.x

26. Varabyova, Y., \& Schreyögg, J. (2013). International comparisons of the technical efficiency of the hospital sector: Panel data analysis of OECD countries using parametric and non-parametric approaches. Health Policy, 112(12), 70-79. https://doi.org/10.1016/j. healthpol.2013.03.003 